\title{
Pengembangan modul online untuk meningkatkan hasil belajar Ilmu Pengetahuan Sosial (IPS)
}

\author{
Ike Arriany *, Nurdin Ibrahim, Mochammad Sukardjo \\ Universitas Negeri Jakarta. \\ Jl. R.Mangun Muka Raya, Rawamangun, Pulo Gadung, Jakarta Timur, DKI Jakarta 13220, Indonesia. \\ ike.arriany@gmail.com \\ * Corresponding Author
}

\section{ARTICLE INFO}

\section{Article History}

Received:

14 February 2019;

Revised:

18 February 2019;

Accepted:

9 October 2020

\section{Keywords}

Belajar mandiri;

Modul;

Modul online;

Pembelajaran online;

Independent learning;

Module;

Online learning;

Online module

\begin{abstract}
Tujuan dari penelitian ini adalah mengembangkan modul online yang efektif untuk meningkatkan ketuntasan hasil belajar Ilmu Pengetahuan Sosial (IPS) di SMP. Modul online ini dikembangkan untuk membantu siswa Sekolah Menengah Pertama (SMP) dalam mencapai standar kompetensi yang ditetapkan pada mata pelajaran IPS. Metode penelitian yang digunakan adalah metode penelitian dan pengembangan. Model yang digunakan untuk mengembangkan modul online untuk meningkatkan hasil belajar IPS adalah model Rowntree dan web based design. Data pada penelitian dan pengembangan ini dikumpulkan berdasarkan quesioner, interview, dokumen hasil belajar, dan test. Hasil uji validasi ahli materi, media, desain instruktional dan uji satu-satu menunjukkan bahwa modul online masuk dalam kategori sangat baik dan layak digunakan dalam pembelajaran IPS. Hasil uji keterbacaan dengan menggunakan fog-index juga menunjukkan teks pada modul online pembelajaran IPS mudah untuk dipahami. Hasil uji lapangan dengan menggunakan perhitungan t-test menunjukkan terdapat perbedaan signifikan terhadap hasil belajar siswa sebelum dan sesudah menggunakan modul dengan kata lain modul online untuk pembelajaran IPS dinilai efektif dan dapat meningkatkan ketuntasan hasil belajar siswa.
\end{abstract}

The purpose of this research is to develop an effective online learning module to enhance student learning results. The development of the module aims at assisting junior high school students to achieve expected competencies in social studies. This research applies Research and Development method. Rowntree and webbased design models are used to develop online modules. All data are collected by document study, questionnaires, tests, and interviews. Based on the expert matter, media expert, instructional design expert, and face to face tryouts, the validity evaluation shows that the online module is appropriate and feasible to use in learning. Moreover, readability judgment using a fog-index score shows that the text is easy to understand. The result of the field trials using the t-test equation shows that there is a significant increase in students' learning results before and after using the module. In conclusion, online module learning is effective to improve students' learning results in order to achieve expected competencies.

This is an open access article under the CC-BY-SA license.

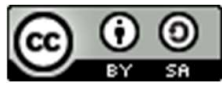




\section{PENDAHULUAN}

Seiring dengan perkembangan zaman yang ditandai dengan kemajuan pesat produk dan pemanfaatan teknologi informasi, penyelenggaraan pembelajaran pun mengalami perubahan dari yang konvensional (tatap muka) menjadi model pembelajaran yang memanfaatkan teknologi informasi. Pembelajaran di abad ke-21 telah bertransformasi yang salah satunya dikarenakan adanya pengaruh pemanfaatan alat komunikasi digital dan aplikasi berbasiskan jaringan online. Hal tersebut menyebabkan terjadinya perubahan karakteristik, kebutuhan, dan permintaan siswa yang membuat pembelajaran pun bergeser kearah pembelajaran mandiri (Alias, DeWitt, \& Siraj, 2015, p. 927). Kemajuan Teknologi Informasi dan Komunikasi (TIK) membuat banyak bahan belajar yang bisa dimanfaatkan oleh siswa untuk memperoleh pengetahuan yang salah satunya adalah melalui media internet. Menurut Panji (2014) yang dipaparkan dalam Kompas, survey mencatat bahwa pengguna internet di Indonesia yang berasal dari kalangan anak-anak dan remaja diprediksi mencapai 30 (tiga puluh) juta jiwa. Penelitian yang dilakukan oleh Triastuti, Prabowo, dan Napis (2017, p. 16) menyebutkan bahwa 80\% anak-anak dan remaja usia pada 10-19 tahun adalah pengguna internet dengan provinsi D.I. Yogyakarta, DKI Jakarta, dan Banten sebagai tiga teratas daerah pengguna internet terbesar di Indonesia.

Motivasi anak dan remaja untuk mengakses internet salah satunya yaitu untuk mencari informasi, sebagai media untuk berkoneksi atau terhubung dengan teman (lama dan baru), dan sebagai media hiburan. Pencarian informasi yang dilakukan sering didorong oleh tugas-tugas sekolah, sedangkan penggunaan media sosial dan konten hiburan di dukung oleh kebutuhan pribadi (Aditya, 2014). Penelitian yang sama terkait dengan motivasi menggunakan internet dan aktivitas online anakanak dan remaja yang dilakukan oleh The United Nations Children's Fund (UNICEF) dan Kementerian Komunikasi dan Informatika Republik Indonesia (Kominfo RI) menyebutkan bahwa sebagian besar motivasi dan aktivitas online yang dilakukan oleh mereka terkait dengan tugas sekolah, mencari informasi, dan bersosialisasi dengan teman melalui media sosial (Triastuti, Prabowo, \& Napis, 2017, p. 17)

Menurut Klimova dan Poulova (2014, p. 15) proses pembelajaran yang berkualitas tentunya menjadi tujuan utama dalam setiap pembelajaran. Pengintegrasian TIK dalam pengembangan bahan belajar harus diupayakan oleh guru, karena terdapat kebutuhan untuk merencanakan pembelajaran yang akan memotivasi siswa untuk belajar. Pengintegrasian TIK dalam pengembangan bahan belajar dapat diterapkan pada semua mata pelajaran, yang salah satunya adalah pelajaran Pendidikan Ilmu Sosial (IPS). Dilihat dari sisi materi, pembelajaran IPS di Sekolah Menengah Pertama (SMP) menarik karena dekat dengan keadaan sehari-hari dan kehidupan nyata. Namun realitasnya mata pelajaran IPS adalah mata pelajaran yang kurang diminati oleh siswa. Pembelajaran IPS kurang mendapat tempat lebih banyak dibanding mata pelajaran lainnya seperti matematika, Ilmu Pengetahuan Alam (IPA), dan Bahasa Inggris atau mata pelajaran lainnya. Hal ini terjadi karena mata pelajaran IPS tidak termasuk dalam mata pelajaran yang di ujian nasionalkan. Selain itu, pembelajaran IPS biasa dilakukan dengan menggunakan pembelajaran konvensional seperti metode ceramah dan menginstruksikan siswanya menulis di buku kerja siswa.

Bertumpunya proses belajar mengajar pada guru menimbulkan kurang tumbuh berkembangnya sikap kemandirian belajar pada siswa. Dilihat dari faktor siswa, banyak siswa yang menganggap bahwa mata pelajaran IPS adalah materi yang membosankan. Kebosanan siswa dengan pembelajaran yang monoton menimbulkan rendahnya minat, motivasi, dan keaktifan siswa untuk berpartisipasi dalam proses pembelajaran. Apabila hal ini terus terjadi, bukan tidak mungkin prestasi siswa mengalami penurunan dan tujuan pembelajaran yang tertuang dalam standar kompetensi lulusan tidak akan tercapai. Berdasarkan data observasi dan wawancara dengan guru mata pelajaran IPS yang dilakukan oleh peneliti di SMP 123 Jakarta Utara, diperoleh informasi sebagai berikut: Pertama, hasil belajar siswa kelas VIII terlihat belum memuaskan. Dengan Nilai Kriteria Ketuntasan Minimum (KKM) yang ditetapkan oleh pihak sekolah yaitu 70, masih terdapat $45 \%$ siswa yang hasil belajarnya dibawah KKM (17 siswa dari total 37 siswa). Bahkan setelah dilakukan remedial melalui retest masih terdapat $40 \%$ siswa ( 7 siswa dari 17 siswa yang remedial) yang hasil belajarnya masih dibawah KKM. 
Kedua, bahan belajar IPS yang saat ini digunakan di SMP 123 Jakarta Timur berupa buku teks, lembar kerja siswa, dan video animasi (powtoon). Ketiga, Metode pembelajaran yang sering digunakan oleh guru dalam menyampaikan materi adalah ceramah, diskusi, dan tanya jawab. Keempat, siswa merasa pelajaran IPS menyulitkan, karena banyaknya materi yang harus dihafalkan. Berdasarkan permasalahan diatas peneliti menyimpulkan bahwa ada beberapa persoalan dalam pembelajaran IPS, yaitu: 1.) Presentase siswa yang belum mencapai kriteria ketuntasan minimum (KKM) yang ditentukan oleh sekolah cukup besar; 2.) Metode pembelajaran yang dilakukan masih terpusat kepada guru, sehingga kurang memfasilitasi kemampuan dasar siswa untuk berpikir logis dan kritis, rasa ingin tahu, inkuiri, memecahkan masalah, dan keterampilan dalam kehidupan sosial; dan 3.) Belum dimanfaatkannya secara maksimal bahan belajar lain selain buku teks dan lembar kerja siwa. Pemanfaatan bahan belajar digital atau yang berintegrasi dengan TIK masih terbatas menggunakan media powerpoint dan pencarian data atau material pendukung pembelajaran seperti video dan audio lewat internet. Inovasi pembelajaran sangat diperlukan untuk memberikan pengalaman belajar yang berbeda dan bervariasi agar dapat merangsang minat siswa untuk belajar.

Belajar adalah usaha sadar dan dilakukan secara terencana, sistematis, dan menggunakan metode tertentu untuk mengubah prilaku relatif menetap melalui interaksi dengan sumber belajar. (Sitepu, 2014, p. 180). Belajar menurut Driscoll dalam Smaldino, Lowther, dan Russel (2008, p. 9) adalah perubahan kemampuan yang terus berlanjut akibat pengalaman belajar dan interaksi di dunia. Belajar adalah perkembangan baru dari pengetahuan, keahlian, dan interaksi individu dengan informasi dan lingkungan. Lingkungan belajar diatur oleh guru, termasuk didalamnya fasilitas, kegiatan akademik, suasana emosional, dan teknologi pembelajaran. Gagne dalam Ibrahim (2010, p. 81) menyatakan bahwa belajar adalah suatu perubahan dalam disposisi atau kapabilitas manusia. Perubahan yang menunjukkan kinerja itu disebut belajar. Perubahan hasil belajar dapat diamati dengan membandingkan kinerja sebelum dan sesudah melakukan aktifitas belajar.

Belajar diartikan sebagai suatu proses yang terjadi pada seseorang sebagai suatu pengalaman. Pembelajaran didefinisikan oleh Gagne dalam Pribadi (2009, p. 9) sebagai serangkaian aktivitas yang sengaja diciptakan dengan maksud untuk memudahkan terjadinya proses belajar. Pengalaman belajar yang memberikan ruang bagi siswa untuk belajar menurut ketertarikannya, kemampuan, pribadinya, dan gaya belajarnya. Salah satu jenis bahan belajar yang mendukung pembelajaran yang berpusat kepada siswa (student center learning) adalah modul. Modul merupakan suatu unit progam pembelajaran yang disusun dalam bentuk tertentu untuk keperluan belajar (Ibrahim, 2010, p. 136). Modul sebagai bahan belajar mandiri dapat digunakan oleh siswa tanpa atau dengan bimbingan terbatas dari guru. Pembelajaran mandiri merupakan kegiatan belajar aktif yang didorong oleh niat atau motif untuk menguasai suatu kompetensi guna mengatasi suatu masalah dan dibangun dengan bekal pengetahuan dan kompetensi yang telah dimiliki (Mudjiman, 2011, p 1).

Modul cetak sudah sangat familiar dan teruji untuk meningkatkan pembelajaran mandiri siswa. Namun, perkembangan teknologi telah mendorong perubahan format dokumen yang semula berbentuk cetak menjadi bentuk digital atau elektronik (Kotzer \& Elran, 2012, p. 122). Konsep pembelajaran digital pun telah mendorong pengembangan kemampuan murid dalam komunikasi, komputasi, kolaborasi, dan berpola pikir kritis. Hasil studi Manuel (2017) menyebutkan bahwa 75\% guru percaya bahwa konten pembelajaran digital akan menggantikan buku teks cetak dalam 10 tahun ke depan, dan $81 \%$ guru juga percaya bahwa pemanfaatan teknologi di sekolah memberikan perbedaan positif dalam proses pembelajaran. Menurut Campbell yang dikutip oleh Prawiradilaga (2012, p. 81) menyebutkan bahwa generasi digital memiliki kebiasaan membaca yang berbeda dengan generasi cetak membaca (buku). Generasi digital sangat pemilih, mereka hanya membaca yang dianggap menarik perhatiannya, seperti huruf besar, warna, dan gambar mencolok. Mereka terbiasa membaca dengan menyapu monitor komputer. Hal ini berbeda dengan generasi cetak yang terbiasa membaca mulai dari kiri ke kanan, kata per kata.

Generasi muda lebih memilih menggunakan bahan belajar berbasis elektronik dibandingkan bahan belajar berbasis cetak dan di masa depan kemampuan serta kemanfaatan bahan belajar berbasis elektronik akan semakin meningkat dengan biaya yang dikeluarkan semakin murah (Annan, 2008, p. 153). Dapat disimpulkan bahwa sudah saatnya untuk mengintegrasi proses pembelajaran dengan TIK karena karakteristik belajar siswa semakin menyatu dengan pemanfaatan teknologi informasi dan komunikasi. Salah satu media pembelajaran mandiri yang bisa dipadukan menjadi satu antara 
model pembelajaran, bahan belajar, dan pemanfaatan TIK adalah modul online. Modul online, emodul, e-learning modul, dan modul berbasis website merupakan pengembangan modul cetak dalam bentuk digital. Pengembangan modul online yang dapat dipadukan dengan model pembelajaran tatap muka dipandang mampu meningkatkan hasil belajar siswa (Purwaningtyas, Dwiyogo, \& Hariyadi, 2017, p. 121).

Modul online atau modul elektronik adalah sebuah media digital yang tampilan dan sistematika penulisannya sengaja dibuat seperti modul yang berisikan serangkaian kegiatan pembelajaran yang saling berhubung oleh tautan dan dapat dilengkapi oleh multimedia, serta dijalankan dengan menggunakan komputer berbasis website (Ibrahim, 2010, p. 162). Kebutuhan untuk mengembangkan modul online pada mata pelajaran IPS dilakukan atas dasar pertimbangan sebagai berikut: Pertama, Modul online dapat membantu guru memberikan bahan pengayaan belajar bagi siswa yang belum tercapai hasil belajarnya. Pemberian remedial selama ini hanya dengan cara menugaskan siswa mempelajari kembali materi yang telah disampaikan sebelumnya tanpa bantuan bahan ajar lainnya sehingga pelaksanaan remedial kurang efektif, akibatnya masih terdapat siswa yang belum mencapai KKM walaupun telah dilaksanakan remedial. Pelaksanaan pembelajaran remedial banyak mengalami kendala, antara lain kurangnya bahan ajar yang disediakan guru dan keterbatasan waktu pelaksanaan remedial; Kedua, Modul online mendukung pembelajaran mandiri. Pembelajaran dengan memanfaatkan modul dapat memberikan kesempatan bagi siswa untuk belajar menurut laju belajar dan cara masing-masing.

Ketiga, salah satu karakteristik dari modul adalah self asessment, melalui self assesment siswa dapat mengetahui sampai sejauh mana kemampuan siswa terhadap materi tersebut; Keempat, modul online dapat memberikan kebaharuan belajar untuk siswa. Kebaharuan bahan belajar diharapkan dapat meningkatkan motivasi belajar siswa; Kelima, modul online dapat memberikan keuntungan dalam hal akses, skala ekonomi, memudahkan dalam memperbaharui konten; Keenam, modul online dapat memberi dukungan di luar kelas yang lebih besar kepada siswa melalui ketersediaan bahan belajar dan umpan balik formatif 24 jam dalam seminggu. (Johnston, 2010, p. 210); dan Ketujuh, modul online mampu menyajikan media yang konkrit melalui visual dan video sehingga dapat memberikan informasi yang lebih mendalam terhadap pengetahuan siswa. (Smaldino, Lowther, \& Russell, 2008, p. 9).

Karakteristik modul online dinilai sesuai untuk menuntaskan hasil belajar siswa, karena modul online dapat menyajikan pembelajaran non linear yang memungkinkan siswa untuk mengeksplorasi materi yang ingin dipelajarinya terlebih dahulu sesuai dengan menu-menu pembelajaran yang tersedia. Selain itu dengan karakteristik modul online yang menghargai gaya belajar yang berbeda akan dapat mengakomodir perbedaan dari gaya belajar siswa, sehingga diharapkan modul online dapat membantu siswa dalam mencapai ketuntasan pembelajaran yang diharapkan. Penelitian ini juga mengacu kepada penelitian relevan terdahulu yang memiliki variable yang sama dengan penelitian yang akan telah dilakukan oleh Adwiah, Satyosari, dan Sulton (2017, p. 1797) dalam pembahasannya tentang pengembangan e-module IPS dengan pendekatan kontekstual dan penelitian yang dilakukan oleh Uno dan Ma'ruf (2016, p. 169), tentang pengembangan media IPS berbasis werbsite. Kajian penelitian yang relevan dibutuhkan sebagai pembuktian bahwa terdapat bukti-bukti empiris terhadap penelitian serupa yang pernah dilakukan. Garis besar dari penelitian ini akan mengangkat variable pengembangan yaitu bahan belajar mandiri dengan memanfaatkan media online.

Pada penelitian ini, peneliti akan mengembangkan modul elektronik yang berbasis website (modul online). Modul ini mudah untuk diakses, digunakan kapan dan dimana saja, dengan mengakses pada tautan yang tersedia sehingga siswa dapat langsung mengakses beragam informasi yang tersedia di modul melalui fasilitas komputer ataupun telepon genggam yang terkoneksi dengan internet. Pengembangan modul online pada penelitian ini menggunakan authoring tools. Dabbagh dan Banna-Ritland (2005, p. 273) mendefinisikan authoring tools sebagai software yang memungkinkan pengembang pembelajaran, guru, dan pembelajar untuk mendisain multimedia interaktif dan ling-kungan pembelajaran hypermedia tanpa perlu memahami bahasa pemograman.

Moodle (Modular Object Oriented Dynamic Learning Environment) adalah sebuah aplikasi komputer yang dapat merubah sebuah media pembelajaran kedalam bentuk website. Moodle, yang dikembangkan oleh Martin Dougiamas, sebagai paket perangkat lunak yang dirancang berdasarkan pada teori pengajaran konstruktivisme yang dapat diunduh secara gratis untuk mengembangkan 
kursus dan situs pembelajaran berbasis internet (Mawardi, 2017). Setelah mengkaji literatur dan hasil penelitian tentang Moodle alasan peneliti memilih Moodle sebagai authoring tools yang digunakan untuk mengembangkan modul online adalah bahwa: 1.) LCMS Moodle sudah familiar di kalangan institusi pendidikan di Indonesia. Sudah banyak penelitian pengembangan yang dilakukan dengan menggunakan aplikasi moodle sebagai perangkat mengembangkan e-learning; 2.) Tersedia dalam bahasa Indonesia, sehingga memudahkan guru, siswa dan admin untuk mengakses, dan mengelolanya; 3.) Proses customization yang relatif tidak merepotkan, meskipun kita tidak memahami keahlian pemograman dengan baik; 4.) Pertimbangan praktis, terutama biayanya lebih ringan (kecuali biaya internet) karena bersifat open source, template, dan theme yang disediakan memadai untuk mengakomodir pembelajaran; 5.) Secara empirik berdasarkan hasil penelitian terbukti sebagai LCMS yang handal (Graf \& List, 2005, p. 164); dan 6.) Moodle adalah platform jaringan yang disukai untuk mengembangkan pembelajaran di sekolah dasar hingga menengah (Jin, 2012, p. 1710).

Tujuan dari penelitian ini adalah menghasilkan modul online untuk meningkatkan hasil belajar siswa pada mata pelajaran IPS. Rumusan masalah dalam penelitian dan pengembangan ini adalah: 1.) Bagaimana prosedur pengembangan modul online yang dikembangkan untuk pembelajaran IPS?; 2.) Bagaimana kelayakan modul online yang dihasilkan untuk pembelajaran IPS?; dan 3.) Bagaimana efektivitas modul online yang dikembangkan untuk pembelajaran IPS?. Materi yang dicakup di dalam modul online ini adalah materi IPS kelas VII semester ganjil. Pemilihan materi berdasarkan analisis kebutuhan yang didapat dari hasil wawancara, dokumen hasil belajar siswa, dan observasi peneliti. Materi yang dikembangkan dalam modul online adalah: 1.) Letak dan luas Indonesia; 2.) Potensi sumber daya alam dan kemaritiman Indonesia; dan 3.) Konsep lembaga sosial.

Hasil penelitian pengembangan ini diharapkan dapat memberikan manfaat secara teoritis dan praktis. Kegunaan teoritis dalam penelitian ini adalah penelitian ini diharapkan dapat memberikan masukan dalam pengembangan bahan belajar khususnya bahan belajar agar proses pembelajaran dapat tercapai sesuai dengan tujuan yang di harapkan. Sedangkan kegunaan praktis penelitian ini adalah penelitian ini diharapkan dapat meningkatkan efektifitas pembelajaran, sehingga pembelajaran menjadi lebih efektif dan dapat memotivasi siswa agar mencapai ketuntasan pada pembelajaran IPS, serta hasil dari pengembangan modul online ini dapat memperkaya bukti empirik yang dapat dijadikan sebagai bahan inovasi dalam pengembangan bahan belajar untuk kegiatan pembelajaran IPS.

\section{METODE}

Penelitian ini adalah penelitian pengembangan dengan tujuan menghasilkan atau mengembangkan suatu produk. Penelitian ini dilaksanakan di SMP 123 Jakarta Utara yang beralamat di Jalan Kelapa Gading I No. 6, Kelapa Gading Timur, Jakarta Utara, DKI Jakarta. Sasaran penelitian adalah siswa kelas VII di SMP 123 Jakarta Utara. Sejak tahun pelajaran 2017-2018, siswa kelas VII SMP 123 Jakarta Utara sudah menggunakan kurikulum 2013. Penelitian ini dilaksanakan selama 9 bulan, yaitu pada bulan April sampai dengan Desember 2018. Penelitian ini menghasilkan produk berupa modul cetak, modul online, dan panduan guru

Pengembangan modul online pada mata pelajaran IPS untuk SMP kelas VII menggunakan model rancangan Rowntree (Rowntree, 1994, p. 1) yang dikolaborasikan dengan model pengembangan web-based design (Jolliffe, Ritter, \& Stevents, 2001, p. 61) dengan menggunakan authoring tools Moodle. Pemilihan model Rowntree didasari pada kebutuhan akan acuan dan pedoman untuk pengembangan modul, oleh karena itu diperlukan model yang memiliki karakteristik pengembangan modul. Model web-based design yang memiliki ciri dapat digunakan untuk pengembangan model yang berbasis online learning dan dilakukan secara sistematis. Model ini sebenarnya terdiri dari 18 langkah, pada pengembangan modul online ini pengembang menerapkan 5 langkah karena langkahlangkah lainnya telah dilakukan sesuai dengan langkah pada model Rawntree. Kolaborasi kedua modul ini diharapkan akan dapat meminimalisir kekurangan dan kelemahan selama prosedur pengembangan hingga sampai proses evaluasi selesai dilaksanakan.

Prosedur pengembangan diawali dengan membuat desain naskah cetak dengan menggunakan model Rawntree. Terdapat 3 tahap yang dilakukan yaitu: 1.) Perencanaan; 2.) Persiapan Penulisan; dan 3.) Penulisan dan penyuntingan. Pada tahap ini dihasilkan naskah cetak yang sudah 
divalidasi oleh ahli materi. Selanjutnya, pengembangan modul online dimulai dengan menggunakan model web-based design, dengan langkah-langkah sebagai berikut: 1.) Menentukan pendekatan desain; 2.) Mengembangkan halaman grafis antar muka (interface) dan template; 3.) Mengembangkan flowchart; 4.) Mengembangkan storyboard; dan 5.) Memasukkan semua materi pelajaran. Sebelum produk dideseminasi, terlebih dahulu produk divalidasi, evaluasi, dan revisi. Uji telaah pakar oleh ahli media dan desain pembelajaran, dilanjutkan dengan uji one to one dengan melibatkan 3 orang siswa berkemampuan tinggi, sedang, dan rendah. Uji keterbacaan menggunakan fog index Terakhir uji kelas besar melibatkan 36 siswa dengan memberikan soal pretest dan posttest untuk mengukur efektivitas modul online.

Jenis data dalam penelitian pengembangan ini menggunakan data kualitatif dan kuantitatif. Data kualitatif adalah data tanggapan dari ahli media, desain, materi, dan siswa tentang produk yang dihasilkan, sedangkan data kuantitatif diperoleh dari angket dan hasil belajar. Angket menggunakan skala likert dengan skala 4, yaitu 4 untuk sangat baik, 3 untuk baik, 2 untuk cukup dan 1 untuk kurang (Djaali \& Muljono, 2008, p. 106). Hasil penilaian dari setiap ahli akan diambil rata dan dinterpretasikan dengan menggunakan kriteria penilaian yang dapat dilihat pada Tabel 1 . Rentang interval untuk interprestasi hasil penilaian diukur dengan Rumus 1. Langkah-langkah pengembangan modul online dapat dilihat pada Gambar 1.

Tabel 1. Kriteria Penilaian

\begin{tabular}{ccc}
\hline No. & Rentang Nilai & Kategori \\
\hline 1 & $3,26-4,00$ & Sangat baik \\
2 & $2,51-3,25$ & Baik \\
3 & $1,76-2,25$ & Cukup baik \\
4 & $1-1,75$ & Kurang baik \\
\hline
\end{tabular}

$\mathrm{p}=\frac{\text { Rentang }}{\text { Banyaknya kelas }}=3 / 4=0,75$

(Sudjana, 2002, p. 46)

Prosedur pengembangan modul online diawali dengan melakukan studi analisis kebutuhan. Pada studi analisis kebutuhan ini peneliti melakukan observasi dan wawancara kepada guru pengampu mata ajar dan 3 orang siswa. Secara garis besar wawancara dan observasi tersebut bertujuan untuk: 1.) Mengetahui gambaran pembelajaran dan sarana pembelajaran IPS dan perolehan nilai harian siswa; 2.) Mengetahui karakteristik pembelajar; dan 3.) Mengetahui kebutuhan pembelajaran online. Selain melakukan wawancara kepada guru dan siswa, peneliti juga melakukan wawancara kepada kepala sekolah untuk mengetahui dukungan dari sekolah akan pembelajaran berbasis online. Berdasarkan hasil wawancara dan observasi analisis kebutuhan, dapat disimpulkan bahwa dibutuhkan media pembelajaran yang dapat memfasilitasi guru dalam pembelajaran dan media yang dapat memenuhi gaya belajar siswa, khususnya berbasis teknologi informasi dan komunikasi seperti media pembelajaran berbasis website. Oleh karena itu, pengembangan modul online untuk mata pelajaran IPS sangat diperlukan.

Berpedoman kepada model yang dijadikan rujukan dalam penelitian pengembangan ini, prosedur pengembangan modul online yang akan dikembangkan menggunakan model pengembangan modul Rowntree (1994) dengan tahapan-tahapan: 1.) Perencanaan; 2. Persiapan penulisan; dan 3.) Penulisan. Tahap Perencanaan, tahapan ini dilakukan denan menganalisis hasil penilaian harian siswa kelas VII A sampai dengan VII E (5 kelas) semester ganjil tahun pelajaran 2017/2018 dengan hasil bahwa terdapat sejumlah siswa yang memiliki nilai di bawah 70. Berdasarkan hasil tes harian siswa dilakukan pemetaan terhadap materi-materi yang tidak tercapai kompetensinya. Berdasarkan informasi dari guru dan dokumen studi dari 9 pokok bahasan mata pelajaran IPS kelas VII di semester 1, didapat 3 pokok bahasan yang memiliki nilai capaian di bawah Kriteria Ketuntasan Minimum (KKM). Langkah selanjutnya adalah merancang Garis Besar Isi Modul (GBIM) dan Jabaran Materi (JM). 


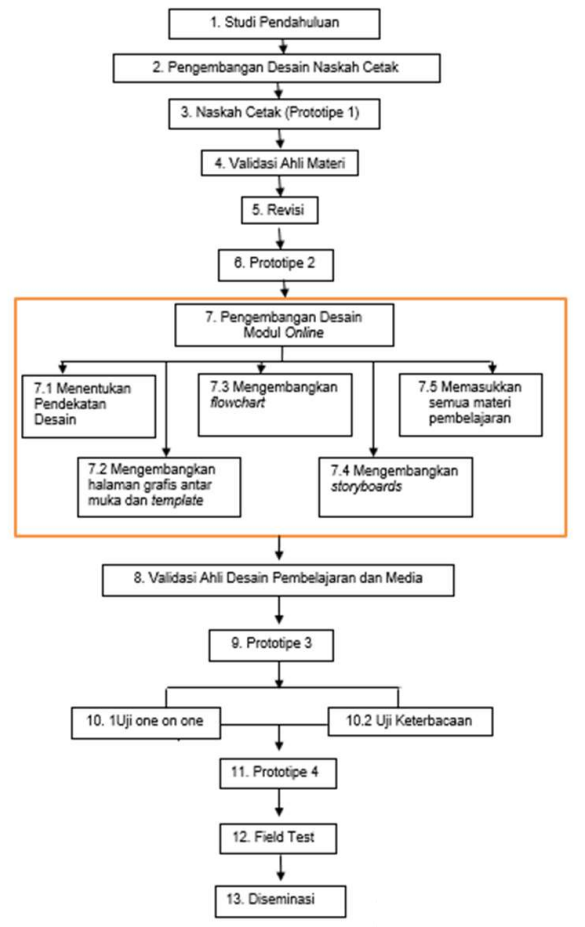

Gambar 1. Prosedur Pengembangan Modul Online

Tahap persiapan penulisan dilakukan dengan menganalisis materi dari buku-buku teks yang digunakan di sekolah, melakukan konsultasi, dan meminta pendapat dari guru pengampu mata pelajaran IPS khususnya tentang materi, tampilan grafis media pembelajaran yang digunakan seperti gambar, tabel, serta kisi-kisi untuk mengembangkan soal-soal formatif dan sumatif. Tahap penulisan dan penyuntingan dilakukan untuk menghasilkan draft modul cetak (prototipe 1). Produk tersebut kemudian dievaluasi dan divalidasi oleh ahli materi. Setelah melalui tahap revisi dan dinilai valid dan layak digunakan dalam pembelajaran oleh ahli materi maka draft tersebut menjadi prototipe 2 yang siap untuk di daringkan.

Langkah-langkah yang digunakan untuk menjadikan prototipe 2 menjadi modul online menggunakan langkah-langkah pengembangan web-based design yang dikembangkan oleh Jolliffe, Ritter, dan Stevens (2001), yaitu: 1.) Menentukan pendekatan desain; 2.) Mengembangkan halaman grafis antar muka (interface) dan templatel 3.) Mengembangkan flowchart; 4.) Mengembangkan storyboard; dan 5.) Memasukkan semua materi pembelajaran. Setelah seluruh materi dimasukkan kedalam bentuk modul online, media tersebut kemudian divalidasi oleh ahli desain pembelajaran dan ahli media yang kemudian dilanjutkan dengan uji one to one, uji keterbacaan, dan uji lapangan.

Hasil dari desain dan draft pertama modul online yang berupa modul cetak (prototipe 1) diberikan kepada ahli materi. Hasil evaluasi dan validasi dari ahli materi, dijadikan panduan untuk melakukan perbaikan terhadap materi untuk modul online yang dikembangkan. Terdapat 6 aspek yang dievaluasi oleh ahli materi, yaitu aspek hasil belajar, aspek relevansi, aspek kelayakan isi, aspek penyajian isi, aspek bahasa, dan aspek evaluasi. Setelah ahli materi melakukan validasi, materi siap untuk dijadikan kedalam bentuk online yang disebut dengan prototipe 2. Prototipe 2 ini kemudian di validasi oleh ahli desain pembelajaran dan ahli media. Ahli desain pembelajaran mengevaluasi 3 yaitu aspek desain pembelajaran, aspek penyajian, dan aspek evaluasi. Ahli media mengevaluasi aspek desain, aspek penyajian, dan aspek petunjuk penggunaan. Untuk mendapatkan data informasi dari para ahli digunakan instrumen dalam bentuk skala nilai dan saran perbaikan.

Setelah mendapat hasil dari validasi dan melalukan revisi atas saran dari ahli desain pembelajaran dan ahli media dihasilkanlah prototipe 3. Prototipe 3 ini kemudian diujikan melalui uji perorangan ke 3 orang siswa yang memiliki kemampuan dengan kategori tinggi, sedang, dan rendah. 
Siswa ini melakukan ujicoba penggunaan modul online dan memberikan informasi berupa komentar, saran yang dengan mengisi angket dan juga wawancara peneliti dengan siswa untuk perbaikan modul. Uji lapangan merupakan evaluasi terakhir yang dilakukan setelah validasi dan revisi pada tahap sebelumnya. Uji lapangan dilakukan terhadap 36 siswa. Pada uji lapangan siswa diberikan angket serta soal pretest dan posttest. Angket tersebut digunakan untuk mengukur kelayakan dari modul online, sedangkan hasil belajar pretest dan posttest digunakan sebagai data untuk mengukur efektivitas modul online. Sebelum menggunakan modul online siswa diminta untuk mengerjakan soal pretest terlebih dahulu. Setelah mengerjakan pretest, peneliti melakukan orientasi kepada siswa bagaimana memanfaatkan modul online dalam pembelajaran IPS. Dalam kegiatan orientasi ini peneliti juga memberikan user id dan password untuk akses siswa, serta menjelaskan sistematika serta cara penggunaan modul online. Siswa diberi waktu selama 5 hari untuk menggunakan modul online sebagai bahan belajar. Diakhir pembelajaran, siswa diminta untuk mengisi posttest untuk mengetahui apakah ada peningkatan hasil belajar siswa.

Pengambilan keputusan apakah terdapat perbedaan yang siginifikan terhadap hasil belajar siswa di ukur dengan menggunakan uji-t. Uji statistik dengan menggunakan rumus uji-t yang dapat dilihat pada Rumus 2 (Sudjana, 2002, p. 239).

$$
t=\frac{\left(\bar{x}_{1}-\bar{x}_{2}\right)}{s \sqrt{\frac{1}{n_{1}}+\frac{1}{n_{2}}}}
$$

Keterangan :

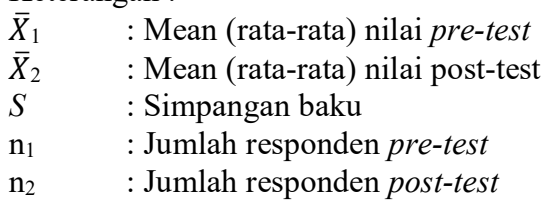

Hipotesis penelitian ini yaitu: terima $\mathrm{H}_{0} \mathrm{Jika}$ t hitung lebih kecil daripada $t$ tabel (0.05); tolak $\mathrm{H}_{0}$ jika t hitung lebih besar daripada $\mathrm{t}$ tabel $(0,05)$.

$$
\begin{aligned}
& \text { Ho: } \mu_{x} \leq \mu_{0} \\
& \text { H1: } \mu_{x}>\mu_{0}
\end{aligned}
$$

\section{HASIL DAN PEMBAHASAN}

Hasil validasi dari ahli materi, diperoleh skor sebesar 4 yang artinya secara umum materi modul online dinilai sangat baik, yang dapat diartikan bahwa produk dan layak digunakan dalam pembelajaran IPS. Secara keseluruhan modul online mendapatkan skor rata-rata 4. Hasil validasi ahli materi dapat dilihat pada Tabel 2, sedangkan grafik rekapitulasi hasil validasi ahli materi dapat dilihat pada Gambar 2.

Tabel 2. Hasil Validasi Ahli Materi

\begin{tabular}{lll}
\hline No. & Aspek & Nilai Rata-Rata \\
\hline 1 & Hasil Belajar & 4 \\
2 & Relevansi & 4 \\
3 & Kelayakan Isi & 4 \\
4 & Penyajian Isi & 4 \\
5 & Bahasa & 4 \\
6 & Evaluasi & 4 \\
\hline
\end{tabular}


Hasil validasi dari ahli desain pembelajaran, diperoleh skor rata-rata sebesar 3,6 yang artinya desain pembelajaran modul online ini dinilai sangat baik, dan layak digunakan dalam pembelajaran IPS. Terdapat 3 aspek yang dievaluasi yaitu aspek desain pembelajaran, aspek penyajian dan aspek evaluasi dengan Aspek penyajian, aspek evaluasi dan aspek desain pembelajaran mendapatkan skor rata- rata 3,6. Hasil validasi ahli desain pembelajaran dapat dilihat pada Tabel 3, sedangkan grafik rekapitulasi hasil validasi ahli desain pembelajaran dapat dilihat pada Gambar 3.

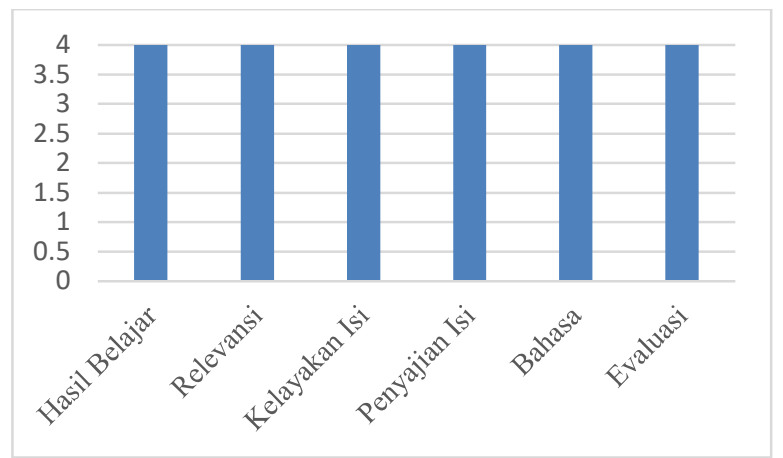

Gambar 2. Grafik Rekapitulasi Hasil Validasi Ahli Materi

Tabel 3. Hasil Validasi Ahli Desain Pembelajaran

\begin{tabular}{lll}
\hline No. & Aspek & Nilai Rata-Rata \\
\hline 1 & Desain pembelajaran & 3,6 \\
2 & Penyajian & 3,6 \\
3 & Evaluasi & 3,6 \\
\hline
\end{tabular}

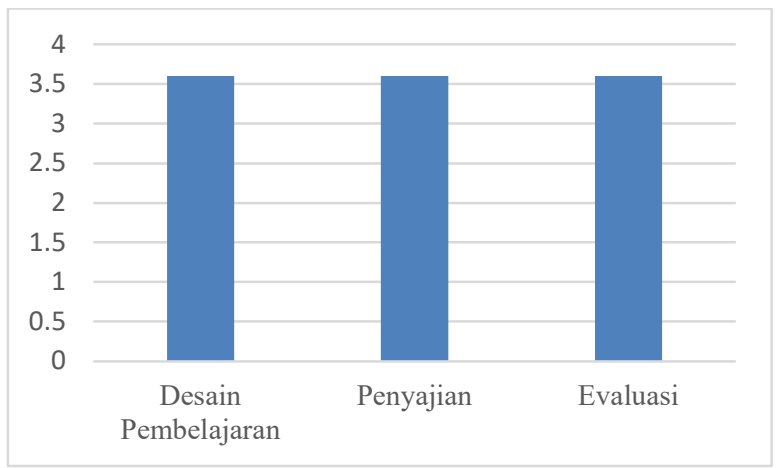

Gambar 3. Grafik Rekapitulasi Hasil Validasi Ahli Desain Pembelajaran

Hasil uji dari ahli media, skor yang diperoleh sebesar 3,68, maka secara umum media yang digunakan dalam modul online ini dinilai sangat baik, yang artinya layak digunakan dalam pembelajaran IPS. Terdapat 3 aspek yang dinilai yaitu aspek desain, aspek penyajian, dan aspek petunjuk penggunaan. Aspek desain mendapatkan rata-rata skor 3,71. Aspek penyajian mendapatkan rata-rata skor 3,71 dan aspek petunjuk penggunaan mendapatkan skor 3,5. Hasil validasi ahli media dapat dilihat pada Tabel 4, sedangkan grafik rekapitulasi hasil validasi ahli media dapat dilihat pada Gambar 4.

Hasil validasi ahli secara keseluruhan terhadap modul online dapat dilihat pada Tabel 5. Berdasarkan rekapitulasi hasil validasi ahli secara keseluruhan dapat disimpulkan bahwa berdasarkan penilaian dari pada ahli, modul online untuk pembelajaran IPS termasuk dalam kategori sangat baik dan layak digunakan dalam pembelajaran. 
Tabel 4. Hasil Validasi Ahli Media

\begin{tabular}{lll}
\hline No. & Aspek & Nilai Rata-Rata \\
\hline 1 & Petunjuk Penggunaan Desain Media & 3,7 \\
2 & Aspek Tampilan & 3,7 \\
3 & Petunjuk penggunaan & 3,5 \\
\hline
\end{tabular}

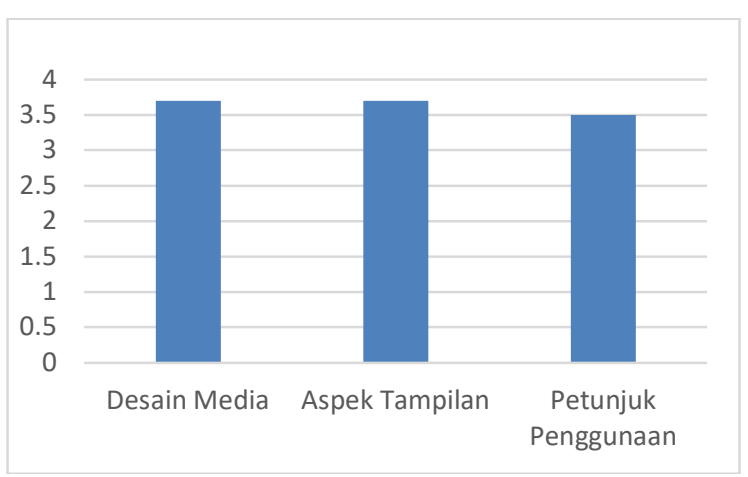

Gambar 4. Grafik Rekapitulasi Hasil Validasi Ahli Media

Tabel 5. Rekapitulasi Hasil Penilaian Validasi Ahli

\begin{tabular}{llll}
\hline No. & Ahli & Rata-rata & Kategori \\
\hline 1 & Materi & 4 & Sangat baik \\
2 & Desain pembelajaran & 3,8 & Sangat baik \\
3 & Media & 3,6 & Sangat baik \\
\hline
\end{tabular}

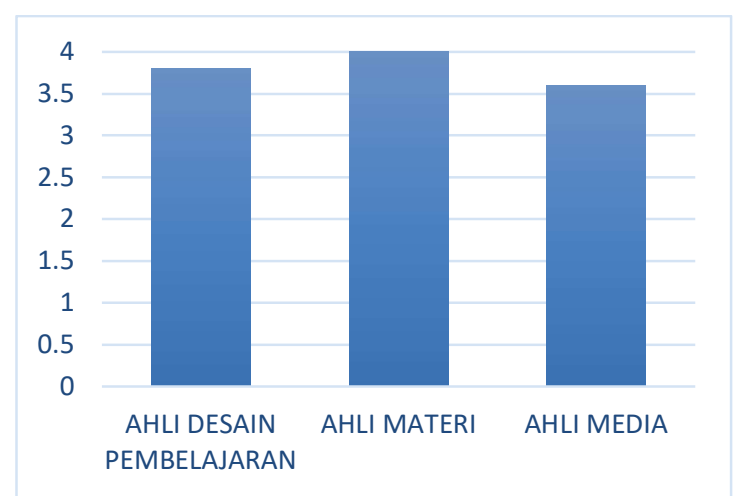

Gambar 5. Grafik Rekapitulasi Hasil Validasi Ahli

Setelah dilakukan validasi oleh para ahli, penelitian dilanjutkan dengan uji one to one, uji keterbacaan dan uji lapangan. Uji coba one to one dilakukan kepada 3 orang siswa dengan kemampuan akademik yang berbeda tinggi, sedang, dan rendah. Uji coba one to one ini dilakukan untuk mengetahui kelayakan produk modul online dilihat dari tiga aspek yaitu aspek aksesbilitas, aspek penyajian, dan aspek manfaat. Proses uji coba one to one dilakukan kepada 3 orang siswa untuk melakukan uji coba modul online. Kegiatan uji coba yang dilakukan adalah siswa diminta untuk mengakses dan menggunakan modul online. Berikut rekapitulasi hasil penilaian uji one to one dapat dilihat pada Tabel 6, sedangkan grafik hasil rekapitulasi uji one to one dapat dilihat pada Gambar 6. 
Tabel 6. Rekapitulasi Hasil Uji Coba One to One

\begin{tabular}{lll}
\hline No. & Aspek & Rata-Rata Penilaian \\
\hline 1 & Aksesbilitas & 3,75 \\
2 & Penyajian materi & 3,83 \\
3 & Aspek manfaat & 3,91 \\
\hline
\end{tabular}

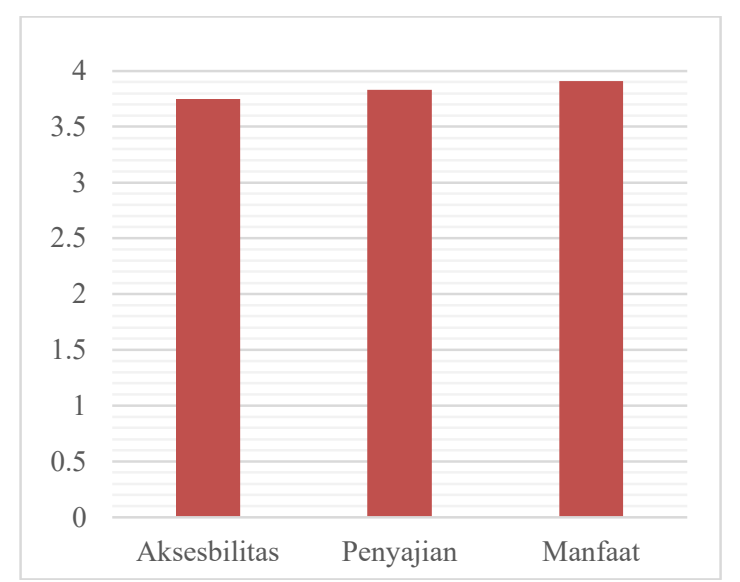

Gambar 7. Grafik Rekapitulasi Hasil Uji One to One

Berdasarkan hasil penilaian uji one to one, produk modul online berdasarkan ketiga aspek tersebut memiliki nilai rata-rata 3,83. Skor ini apabila diinterpretasikan berdasarkan uji one to one masuk dalam kategori sangat baik, yang dapat diartikan bahwa produk ini layak digunakan dalam pembelajaran IPS.

Peneliti mengukur tingkat keterbacaan modul dengan menggunakan fog indeks. Rumus matematikanya ialah: Tingkat keterbacaan $=0,4(\mathrm{RPK}+\mathrm{KS})$. RPK adalah rata-rata panjang kalimat, sedangkan KS adalah kalimat sukar. Apabila hasilnya lebih dari 12 atau $>12$ maka tingkat keterbacaan masuk dalam kategori sangat sukar, apabila $>8-12$ masuk dalam kategori sukar, $>3-7$ masuk dalam kategori mudah, dan $<3$ masuk dalam kategori terlalu mudah. Menurut Sitepu (2015, pp. 122) hasil ideal untuk tingkat keterbacaan untuk karakteristik siswa usia 14-16 tahun adalah $<8$ (dibawah 8). Hasil hitung uji keterbacaan yang mewakili dari tiga modul yang dikembangkan dapat dilihat pada Tabel 7.

Tabel 7. Angka Keterbacaan Modul

\begin{tabular}{lll}
\hline Modul & Angka keterbacaan & Kategori \\
\hline Pemahaman lokasi melalui peta & 5,78 & Mudah \\
Potensi sumber daya alam dan & 6,76 & Mudah \\
kemaritiman Indonesia & 6,83 & Mudah \\
Lembaga sosial & &
\end{tabular}

Hasil perhitungan keterbacaan dari empat pokok bahasan diperoleh skor rata-rata keseluruhan 6,45. Hasil ini menyatakan bahwa modul online dari segi tingkat keterbacaan dikategorikan mudah. Ujicoba selanjutnya adalah ujicoba lapangan dengan subjek sebanyak 36 siswa. Ujicoba dilakukan untuk mendapatkan penilaian tentang kelayakan dan efektifitas produk yang dikembangkan. Berdasarkan hasil uji coba lapangan diperolah skor rata-rata keseluruhan 3,3. Hasil ini menyatakan bahwa modul online dilihat dari aspek aksesbilitas, penyajian, dan manfaat dinilai sangat baik dan layak digunakan dalam pembelajaran IPS. Grafik rekapitulasi hasil penliaian produk pada uji coba lapangan dapat dilihat pada Gambar 8 .

Berdasarkan hasil uji kelayakan secara teoritis dan empiris menunjukan bahwa modul online berada pada kategori yang sangat baik. Sesuai dengan hasil analisis tersebut dapat disimpulkan 
bahwa modul online yang dikembangkan memenuhi kriteria valid dan layak digunakan dalam pembelajaran IPS. Rekapitulasi hasil evaluasi kelayakan modul online dapat dilihat pada Tabel 8.

Uji efektivitas atas hasil belajar siswa dilihat dari hasil pretest dan post test. Berdasarkan data hasil belajar siswa presentase ketuntasan hasil belajar siswa setelah menggunakan modul online (post-test) sebesar 81\%, dimana siswa yang memenuhi KKM sebanyak 29 orang dari 36, dibandingkan hasil pretest dimana hanya hanya 8 orang saja yang memenuhi KKM $>70$. Apabila dilihat dari rata-ratanya dapat diketahui bahwa rata-rata nilai pretest adalah 60.00 sedangkan ratarata nilai posttest adalah 78,5 sehingga dapat disimpulkan bahwa modul online terbukti efektif sebagai sumber belajar yang dapat meningkatkan hasil belajar siswa. Peneliti melakukan uji-t untuk mengetahui apakah terdapat perbedaan kenaikan yang signifikan antara pretest dan post-test. Uji ini bertujuan untuk membuktikan apakah terdapat perbedaan yang signifikan terhadap hasil belajar siswa sebelum dan sesudah menggunakan modul online.

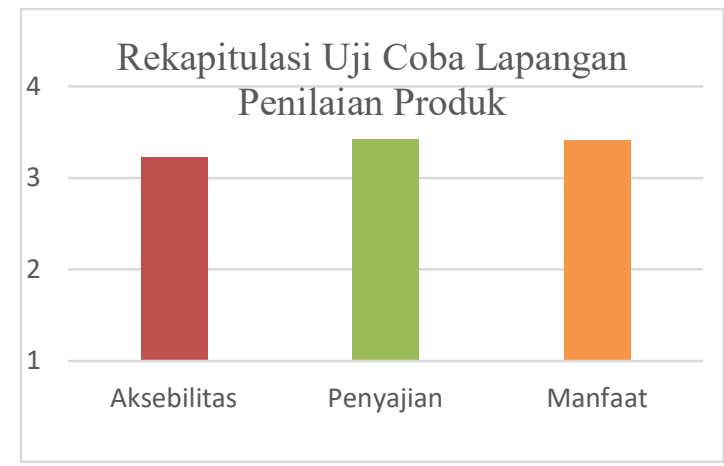

Gambar 8. Grafik Rekapitulasi Hasil Penilaian Produk pada Uji Coba Lapangan

Tabel 8. Rekpitulasi Hasil Evaluasi Kelayakan Modul Online

\begin{tabular}{clll}
\hline No. & Evaluasi & Rata-Rata & Kategori \\
\hline 1 & Ahli materi & 4 & Sangat baik \\
2 & Ahli desain pembelajaran & 3,8 & Sangat baik \\
3 & Ahli media & 3,6 & Sangat baik \\
4 & Satu-satu & 3,8 & Sangat baik \\
5 & Keterbacaan & 6,45 & Mudah \\
6 & Lapangan & 3,3 & Sangat baik \\
\hline
\end{tabular}

Hasil perhitungan dengan menggunakan t-test, diperoleh t hitung adalah 7,42 sedangkan ttabel dengan taraf signifikansi 0,05 adalah 1,66 artinya T-hitung $>$ t-tabel, sehingga Ho di tolak. Oleh karena itu, dapat disimpulkan bahwa terdapat perbedaan yang siginifikan terhadap hasil belajar siswa, sehingga dapat dinyatakan bahwa modul online efektif untuk meningkatkan hasil belajar siswa SMP pada mata pelajaran IPS. Hasil penelitian pengembangan modul online menunjukkan modul online sangat dibutuhkan karena adanya kendala dalam pelaksanaan pembelajaran. Oleh karena itu, pembelajaran melalui modul bisa menjadi solusi untuk mengatasi kendala pada pembelajaran. Modul dengan karakteristik belajar mandiri, memberikan kesempatan kepada pada siswa untuk belajar menurut cara dan pace masing-masing siswa. Modul online dikemas dengan tema atau topik tertentu berdasarkan atas kebutuhan dila-pangan. Pemilihan tema dan topik ditentukan berdasarkan data indikator yang sulit dipahami oleh siswa. Indikator tersebut diidentifikasi melalui nilai ulangan harian siswa dan pengamatan proses belajar di kelas oleh guru.

Di era revolusi digital, pemanfaatan teknologi sudah tidak asing lagi dalam proses pembelajaran. Perkembangan TIK khususnya teknologi internet mampu memberikan kemudahan dan keleluasaan dalam menggali ilmu pengetahuan. Siswa dapat mengakses berbagai literatur dan referensi ilmu pengetahuan yang dibutuhkan dengan cepat, kapan saja, dan dimana saja, sehingga 
dapat mempermudah proses belajarnya. Pada umumnya, fasilitas media pembelajaran yang tersedia di sekolah utamanya di kota besar sudah dilengkapi dengan laboratorium, ruang komputer dengan jaringan internet, wi-fi, serta layanan internet secara luas di lingkungan sekolah. Kesimpulannya adalah saat ini teknologi adalah pendamping belajar siswa.

Penyajian modul dalam bentuk online akan menjadikan pembelajaran menjadi lebih menarik dan memberikan berbagai kemudahan bagi siswa untuk memahami materi pembelajaran karena modul online ini difasilitasi dengan gambar, animasi, audio, dan video yang mampu menjelaskan materi yang bersifat abstrak dan sulit dipahami. Selain itu, kemudahan akses waktu dan tempat yang difasilitasi oleh modul online dapat membuat siswa belajar kapan saja dan dimana saja. Menurut Sanjaya (2013, p. 246) belajar menurut teori konstruktivisme adalah proses mengkontruksi pengetahuan melalui pengalaman. Pengetahuan bukanlah hasil pemberian dari orang lain seperti guru, akan tetapi hasil dari proses mengkonstruksi yang dilakukan oleh setiap individu. Dengan menggunakan modul online siswa dapat mengkontruksi sendiri pengetahuannya melalui pengalaman belajar secara online.

Peneliti dalam proses mengembangkan modul online ini memiliki beberapa hambatan yaitu: 1.) Kesulitan dalam menterjemahkan materi dalam bentuk teks yang panjang kedalam bentuk media online karena materi harus dibuat semenarik mungkin dengan menghindari teks yang panjang; 2.) Kesulitan dalam membangun interaktivitas siswa dengan guru, siswa dengan materi sebagai upaya untuk menciptakan pembelajaran sebagaimana layaknya pembelajaran tatap muka; 3.) Adanya kendala teknis yaitu server website mengalami down dan gangguan (password admin dan siswa invalid) ketika proses pengembangan dan uji coba yang berakibat adanya database yang hilang atau tidak tersimpan karena tidak ter-backup; dan 4.) Keterbatasan kemampuan peneliti mengenai hal teknis terkait database seperti kurang pahamnya pada bahasa Hypertext Markup Language (HTML) sebagai bahasa pemrograman yang digunakan dalam database yang mengakibatkan peneliti kesulitan ketika ada terjadi kendala teknis dalam pengembangan modul online.

Hambatan tidak menjadikan pengembangan modul online ini sulit untuk dikembangkan, justru semakin menantang untuk terus mengembangkan pembelajaran dengan menggunakan modul online, karena keunggulannya sebagai berikut: 1.) Modul dapat diakses melalui browser apa saja dengan menggunakan device komputer, laptop, tablet, dan smartphone yang terhubung jaringan internet; 2.) Modul dapat diakses kapan saja dan di mana saja dengan menggunakan perangkat yang dapat terhubung jaringan internet; 3.) Modul yang dikembangngkan dalam penelitian ini dilaksanakan fully online tanpa ada tatap muka, sehingga mampu untuk meningkatkan pengalaman belajar mandiri bagi siswa; 4.) Siswa dapat mencapai hasil belajarnya sesuai dengan kemampuan dan pace belajarnya; 5.) Modul dapat meningkatkan motivasi belajar siswa karena fitur-fitur media yang disajikan dalam modul online; 6.) Sistem navigasi dirancang seefektif mungkin dan mudah untuk digunakan oleh siswa; dan 7.) Modul ini dilengkapi dengan evaluasi mandiri untuk mengukur hasil belajar siswa dan hasilnya dapat diketahui secara langsung. Peneltian dan pengembangan ini belumlah sempurna, karena ada beberapa kelemahan yang dimiliki dalam mengembangkan modul online, yaitu: 1.) Untuk mengakses modul online dibutuhkan kualitas jaringan internet yang memadai agar modul online dapat diakses dengan baik, dan waktu delay dari mengakses media dapat diminimalisir; dan 2.) Membutuhkan sumber daya yang mumpuni untuk mengelola pembelajaran berbasis online agar pembelajaran lebih menarik dan efektif.

\section{SIMPULAN}

Pengembangan modul online sebagai bahan belajar mandiri merupakan solusi untuk memfasilitasi kegiatan belajar sebagai upaya untuk meningkatkan hasil belajar siswa. Pengembangan modul online dilakukan dengan menggunakan model pengembangan Rawntree dan web-based design. Dimulai dari tahap perencanaan, tahap pengembangan (naskah modul cetak dan modul online), dan tahap evaluasi, sehingga diperoleh kesimpulan bahwa modul online sangat baik dan layak untuk di gunakan untuk pembelajaran IPS. Hasil validasi menurut ahli materi, ahli desain pembelajaran dan ahli media, dan uji keterbacaan diperoleh hasil modul online yang dikembangkan dari segi desain pembelajaran, kelayakan isi dan media memiliki kategori sangat baik dan keterbacaannya mudah sehingga layak digunakan dalam pembelajaran IPS. 
Berdasarkan hasil uji-t yang telah dilakukan terhadap hasil belajar siswa, diperoleh hasil thitung lebih besar daripada t-tabel. Hal tersebut dapat disimpulkan bahwa terdapat perbedaan hasil yang signifikan terhadap hasil belajar siswa sebelum dan sesudah test, sehingga dapat dinyatakan bahwa modul online untuk pembelajaran IPS efektif untuk meningkatkan hasil belajar siswa. Pembelajaran dengan modul online akan membuat siswa membiasakan diri untuk belajar mandiri dan juga memberikan alternatif bahan belajar dengan memuat visualisasi multimedia yang dapat memudahkan siswa memahami materi. Peneliti berharap akan ada penelitian lain tentang modul online dengan materi pada mata pelajaran yang sama atau dengan materi pelajaran lain dengan kualitas yang lebih baik dari segi materi, media, dan memberikan kemudahan yang lebih dalam hal mengakses materi dalam modul online.

\section{DAFTAR PUSTAKA}

Adwiah, R., Setyosari, P., \& Sulton, S. (2016). Pengembangan e-module IPS dengan pendekatan kontekstual untuk siswa kelas VII SMPK Mater Dei Probolinggo. Jurnal Pendidikan: Teori, Penelitian, dan Pengembangan, 1(9), 1797-1805. doi: http://dx.doi.org/10.17977/jp.v1i9.6816

Alias, N., DeWitt, D., \& Siraj, S. (2015, May). The effectiveness of physics PTechLS module in a rural secondary school in Malaysia. In International Educational Technology Conference 2015, Instanbul, Turkey.

Annand, D. (2008). Learning efficacy and cost-effectiveness of print versus e-book instructional material in an introductory financial accounting course. Journal of Interactive Online Learning, 7(2), 152-164.

Dabbagh, N., \& Bannan-Ritland, B. (2005). Online learning: Concepts, strategies, and application. Upper Saddle River, New Jersey: Pearson/Merrill/Prentice Hall.

Djaali, H., \& Muljono, P. (2008). Pengukuran dalam bidang pendidikan. Jakarta: Grasindo.

Graf, S., \& List, B. (2005, July). An evaluation of open source e-learning platforms stressing adaptation issues. In $5^{\text {th }}$ IEEE International Conference on Advanced Learning Technologies (ICALT'05) (pp. 163-165). Institute of Electrical and Electronics Engineers (IEEE), United States.

Ibrahim, N. (2010). Perspektif pendidikan terbuka jarak jauh. Jakarta: Bumi Aksara.

Jeghesta, M. (2017, October 9). Wujudkan transformasi digital, dunia pendidikan implementasikan digital classroom. Seputar Indonesia News, Retrieved from https://autotekno.sindonews.com/read/1246685/123/wujudkan-transformasi-digital-duniapendidikan-implementasikan-digital-classroom-1507534024.

Jin, S. (2012, July). Design of an online learning platform with Moodle. In $20127^{\text {th }}$ International Conference on Computer Science \& Education (ICCSE) (pp. 1710-1714), Institute of Electrical and Electronics Engineers (IEEE), United States.

Johnston, N. (2010). Is an online learning module an effective way to develop information literacy skills?. Australian Academic \& Research Libraries, 41(3), 207-218. doi: https://doi.org/10.1080/00048623.2010.10721464

Jolliffe, A., Ritter, J., \& Stevens, D. (2012). The online learning handbook: Developing and using web-based learning. Routledge.

Klimova, B. F., \& Poulova, P. (2014, February). ICT as a motivational tool in the learning of foreign languages. In Proceedings of the 2014 International Conference on Educational Technologies and Education (ICEduTech) (pp. 53-56), New Tapei City, Taiwan.

Kotzer, S., \& Elran, Y. (2012, September). Learning and teaching with Moodle-based E-learning environments, combining learning skills and content in the fields of Math and Science \& 
66 - Jurnal Inovasi Teknologi Pendidikan

Technology. In $1^{\text {st }}$ Moodle Research Conference, Heraklion, Crete-Greece. Retrieved from https://research.moodle.org/55/1/16\%20-\%20Kotzer\%20-

\%20Learning\%20and\%20teaching\%20with\%20Moodle-based\%20E-learning.pdf

Mawardi, M. (2014) Pemilihan web-based instructional authoring tools dalam pengembangan pembelajaran berbasis e-learning. Scholaria, 4(1), 1-14). Retrieved from https://adoc.pub/pemilihan-web-based-instructional-authoring-tools-dalam-peng.html

Mudjiman, H. (2011). Belajar mandiri (pembekalan dan penerapan). Surakarta: UNS Press dan LPP UNS.

Panji, A. (2014, February 19). Hasil survei pemakaian internet remaja Indonesia. Kompas. Retrieved from

http://tekno.kompas.com/read/2014/02/19/1623250/Hasil.Survei.Pemakaian.Internet.Remaj a.Indonesia.

Pribadi, B. A. (2009). Model desain sistem pembelajaran. Jakarta: Dian Rakyat.

Prawiradilaga, D. S. (2012). Wawasan teknologi pendidikan. Jakarta: Kencana Prenada Media Group.

Purwaningtyas, P., Dwiyogo, W. D., \& Hariyadi, I. (2017). Pengembangan modul elektronik mata pelajaran pendidikan jasmani, olahraga, dan kesehatan kelas XI berbasis online dengan program Edmodo. Jurnal Pendidikan: Teori, Penelitian, dan Pengembangan, 2(1), 121-129. doi: http://dx.doi.org/10.17977/jp.v2i1.8471

Rowntree, D. (1994). Preparing materials for open, distance and flexible learning: An action guide for teachers and trainers. Routledge.

Sanjaya, W. (2013). Kurikulum dan pembelajaran. Jakarta: Media Grafika.

Smaldino, S. E., Lowther, D. L., Russell, J. D., \& Mims, C. (2008). Instructional technology and media for learning. New Jersey: Pearson Education.

Triastuti, E., Prabowo, A. I., \& Napis, H. V. (2017). Peta jalan perlindungan anak Indonesia di internet. Kementerian Komunikasi dan Informatika Republik Indonesia \& Komisi Perlindungan Anak Indonesia.

Uno, H. B., \& Ma'ruf, A. R. K. (2016). Pengembangan media pembelajaran IPS berbasis website untuk siswa kelas VII Madrasah Tsanawiyah Negeri. Jurnal Teknologi Pendidikan, 18(3), 169-185. doi: https://doi.org/10.21009/jtp.v18i3.5372 